University for Business and Technology in Kosovo

UBT Knowledge Center

UBT International Conference

2017 UBT International Conference

Oct 28th, 11:00 AM - 12:30 PM

\title{
Impact of Usage of ICT and Performance on Quality in Higher Education Institutions: An Empirical Study
}

\author{
Hasan Metin \\ University for Business and Technology, hasan.metin@ubt-uni.net \\ Esra Metin \\ University for Business and Technology, esrakaytas@hotmail.com \\ Gjylbehare Llapi \\ University for Business and Technology, gjylbehare.llapi@ubt-uni.net \\ Dukagjin Hyseni \\ University for Business and Technology, hysenidukagjin@gmail.com
}

Follow this and additional works at: https://knowledgecenter.ubt-uni.net/conference

Part of the Education Commons

\section{Recommended Citation}

Metin, Hasan; Metin, Esra; Llapi, Gjylbehare; and Hyseni, Dukagjin, "Impact of Usage of ICT and Performance on Quality in Higher Education Institutions: An Empirical Study" (2017). UBT International Conference. 123.

https://knowledgecenter.ubt-uni.net/conference/2017/all-events/123

This Event is brought to you for free and open access by the Publication and Journals at UBT Knowledge Center. It has been accepted for inclusion in UBT International Conference by an authorized administrator of UBT Knowledge Center. For more information, please contact knowledge.center@ubt-uni.net. 


\title{
The Impact of Usage of ICT and Peformance on Quality in Higher Education Institutions: An Empirical Study
}

\author{
Hasan Metin, Esra Metin, Gjylbehare Llapi, Dukagjin Hyseni \\ UBT-Higher Education Institution, Lagjja Kalabria, 10000 n.n., \\ Prishtina, Kosovo \\ hasan.metin@ubt-uni.net; esrakaytas@hotmail.com; gjylbehare.llapi@ubt-uni.net; \\ hysenidukagjin@gmail.com
}

\begin{abstract}
This study presents the relationship among the quality, performance and usage of ICT in higher education. The conceptualization of quality relies on applicable knowledge and accomplishment of goals set in curricula of the subject/program- effective learning. The conceptualization of the performance is participation in active learning, to be able to finalize the tasks on time, getting high test scores, and students' progress in general. Lastly, the usage of ICT is understood as teaching and learning by using technology tools and resources- efficient learning. The results indicate that participation in the active learning, getting high test scores, and students' progress have positive effects on applicable knowledge and accomplishment of goals set in curricula of the subject/ program- effective learning. Moreover, teaching and learning by using technology tools and resources- efficient learning again have positive effects on applicable knowledge and accomplishment of goals set in curricula of the subject/ program- effective learning.
\end{abstract}

Keywords: ICT1, Quality2, Performance3

\section{Introduction}

Usage of ICT Information and Communication Technologies (ICT) has gained its importance due to enormous and continuous developments in every aspect of life. The classical way of lecturing and teaching techniques cannot keep with the advancements of the social life. Life outside the school is very fast and the classical methods cannot keep the students active enough in the classroom that is why students cannot increase their performance, they cannot participate in active learning, they are not able to finalize the tasks that are previously established and progress in general. Quality assurance is very critical for higher education institutions to be able to satisfy the expectations of the stakeholders in a best way. This study presupposes that, quality is very closely related with increasing the performance and usage of ICT.

\section{Performance}

Performance management and performance measurement are two very fundamental concepts under the concept of performance within management discipline which can be used interchangeably that, there is no consensus on how to define them and determine the differences in defining them. Since there is no consensus on the definition of performance, it is closely related with effectiveness, efficiency and productivity (Ammons ,1996) that determination of objectively 
verifiable indicators and assessing whether they have been achieved is the simplest way of explaining the performance management or performance measurement.

Performance is measured almost in every sector ranging from public sector to third sector (Metin, 2017; Metin \& Coskun, 2017) and several profit-seeking sectors. Performance measurement can be implemented in many different ways through using both financial and non-financial indicators. Usage of non-financial indicators in performance measurement became a trend in 90s (Kaplan \& Norton, 1995). The balance score card is a performance measurement tool that is widely accepted and used in various sectors including educational institutions, that emphasizes the importance of using both financial and non-financial indicators in performance measurement attempts.

The literature review on performance management and performance measurement in educational sector focuses on different areas varying from public education (Smith \&Meier,1995a; Wrinkle \&Steward \& Polinard, 1999; \&Guthrie, 2009) to higher education (Richardson,1995; Berg,1972; Ferris,1992; Brown,1999; Clifford \&Guthrie, 1990) from quality in education (Smith \& Meier,1995b; Guthrie\& Neumann, 2007; Kurien, 1981) to evaluation (Callan \& Doyle \& Finney, 2001) and diversity in education (Ely,2004).

Performance is a very broad concept that it can be analyzed in an institutional level, divisional level or individual level. This study conceptualizes performance in the individual level through participation in active learning, to be able to finalize the tasks that are previously established, getting high test scores, and students' progress in general. It is presupposed that increase in the performance within individual level will have a positive effect on the quality of the services of the higher educational institutions.

\section{Quality}

Quality is the dependent variable of this study that, the effects of performance and usage of ICT on quality in higher education institutions is the research question of this study.

Quality assurance in higher education has become a new academic area in the area of educational development lately. Quality assurance practices are transferred or modified from profit seeking institutions and quality assurance has been seen in the importance of involvement of stakeholders and the value they bring in the higher education development.

The standards used with respect to quality assurance within the European Universities have been guided with the introduction of the European Higher Education Area, known otherwise as Bologna Process. The main aim of the Bologna Process is to introduce and implement common principles and standards of higher education in the member countries. The umbrella institution for quality assurance in European Union is European Association for Quality Assurance in Higher Education (ENQA). Kosovo Accreditation Agency focuses the standards and guidelines for internal quality assurance, which basically guide higher education institutions to have internal policy and structures continually ensuring and checking quality assurance internally in Kosovo.

\section{The Usage of ICT in Teaching and Learning}

The application of information technology (IT) into the learning process: the blackboard and chalk remain the primary teaching technologies in many business schools even while the merits of information technology to improve communication, efficiency and decision making in organizations are recognized and inculcated by IS researchers. However, as business schools experience increased competitive pressures, information technology is one area that schools might use to differentiate or compete with or, more importantly, to use as a catalyst for transforming educational processes). 
Information and communications technology (ICT) is an accepted element in all our lives and has a central role to play in education. Since the appearance of the first government policy on ICT in education in 1997, a substantial investment has been made in ICT facilities and training in Irish schools. In Ireland, as in other countries, the debate about ICT in education focuses on the potential impact of ICT on teaching and learning and on the measures that need to be adopted to ensure that the potential of ICT to enrich students' learning experience is realized.

Even though the role of ICT in enhancing learning outcomes is a contested one, most of the researches done in this area suggest that there are number of benefits that ICTs bring to the knowledge creation, management and dissemination frontier. Some of the perceived benefits include: improved access to information, creation of an enabling environment for a wider participation in higher education, improvement of communication among students and between students 2 and teachers, (Hill et al 2004) promotion of collaborative learning and supporting learner -centered approaches to teaching, increased flexibility and the development of competence-based curriculum.

Factors which influence teachers' decisions to use ICT in the classroom: Access to resources, quality of software and hardware, ease of use, incentives to change, support and collegiality in their school, school and national polices, commitment to professional learning and background in formal computer training. This highlight the role of pedagogy and suggests that teachers' beliefs about teaching and learning with ICT are central to integration. It is suggested that successful implementation of ICT needs to address three interlocking frameworks for change: The teacher, the school, and policy makers.

\section{Methodology}

Linear regression has been utilized in order to determine the effect of the independent variables of the study (performance and usage of ICT) the dependent variable quality. Statistical Package for the Social Sciences (SPSS) has been used for the analysis. The hypotheses of the study are as follows:

Hypothesis 1: Usage of ICT has a positive effect on quality in Higher Education Institutions in Kosovo

Hypothesis 2: Performance has a positive effect on quality in Higher Education Institutions in Kosovo

Below are tables derived from the SPSS.

Table 1. Model Summary

\begin{tabular}{llllll}
\hline & & & \multicolumn{2}{c}{ Std. Error } \\
Model & $\mathrm{R}$ & R Square & $\begin{array}{l}\text { Adjusted } \\
\text { R Square }\end{array}$ & $\begin{array}{l}\text { of } \\
\text { Estimate }\end{array}$ & $\begin{array}{l}\text { Durbin- } \\
\text { Watson }\end{array}$ \\
\hline 1 & $.618^{\mathrm{a}}$ & .382 & .360 & .51270 & 1.734 \\
\hline
\end{tabular}

This indicates that the adjusted $\mathrm{R}$ square is 0.38 meaning that the indedepenedent varaibles explain the 38 percent of the total effect on quality. Durbin Watson figure will be mentioned below when analsysing the assumotions of regression. 
Table 2. ANOVA

\begin{tabular}{lllllll} 
& & \multicolumn{3}{l}{ Sum of } & \multicolumn{2}{l}{ Mean } \\
Model & Squares & df & Square & F & Sig. \\
\hline 1 & Regression & 9.114 & 2 & 4.557 & 17.337 & $\mathbf{. 0 0 0}$ \\
& Residual & 14.720 & 56 & .263 & & \\
\multicolumn{1}{l}{ Total } & 23.835 & 58 & & & \\
\hline
\end{tabular}

This indicates that the signifance of the model in general is .000 which is acceptable at the 99 percent confidence level.

Table 3. Coefficients

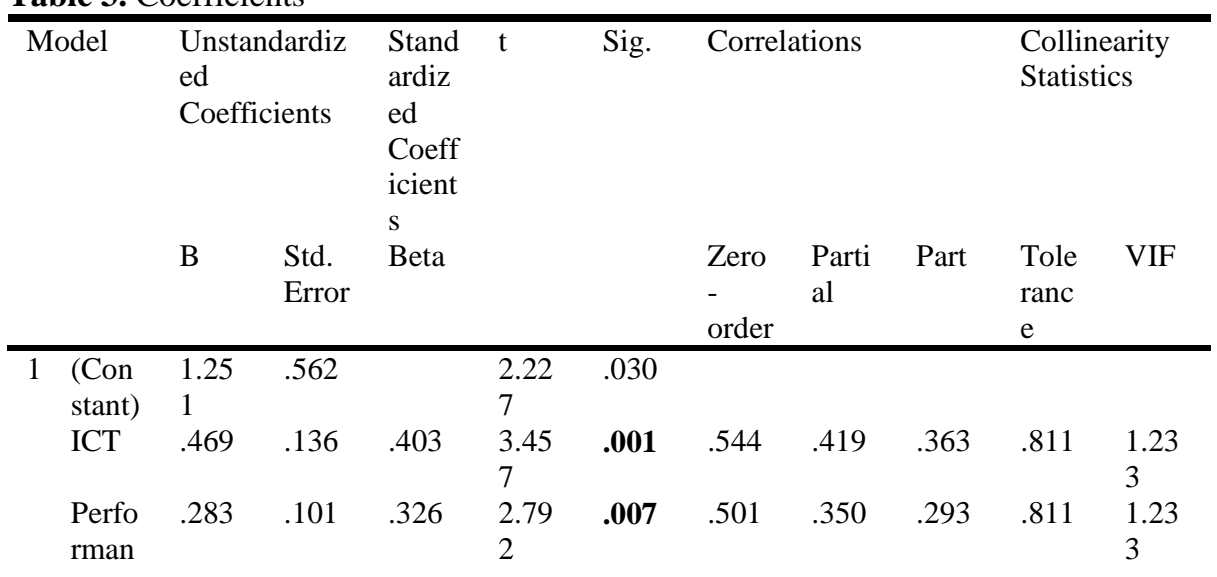

This indicates that both usage of ICT and Performance have accapateble significance levels at the 99 percent confidence level.

So the regression function is

Quality $=1.251+0.469$ ICT +0.283 Performance

The assumptions of Regression model should be checked as well.The first assumption is normality assumption of the resudiuals.

Histogram

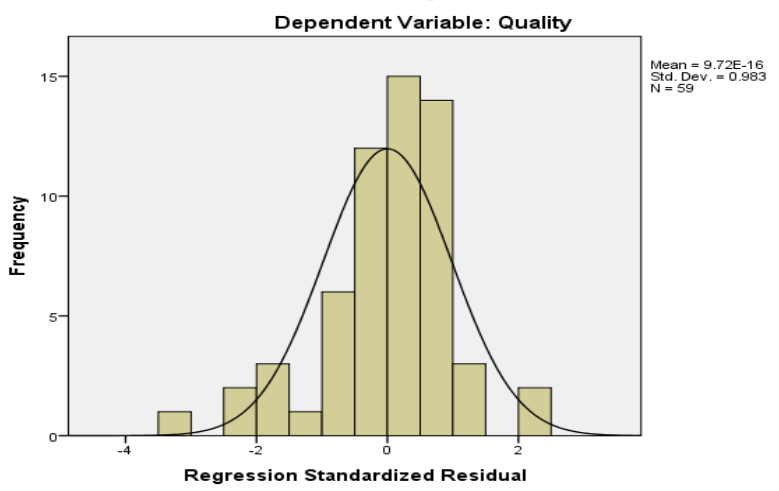

Fig. 1. Normality 


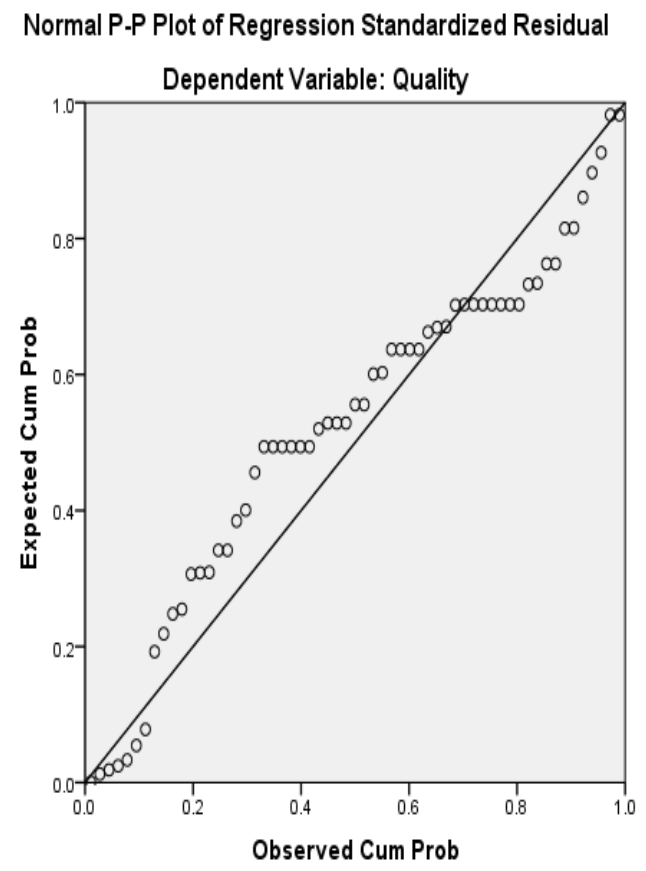

Fig. 2. Normality

Given the figures above it can be concluded that the residuals are normally distributed.

\section{Multicollinearity}

Multicollinearity does not seem to be a oroblem because the VIF figures are 1,233 (less than 10) 


\section{Heteroscedasticity}

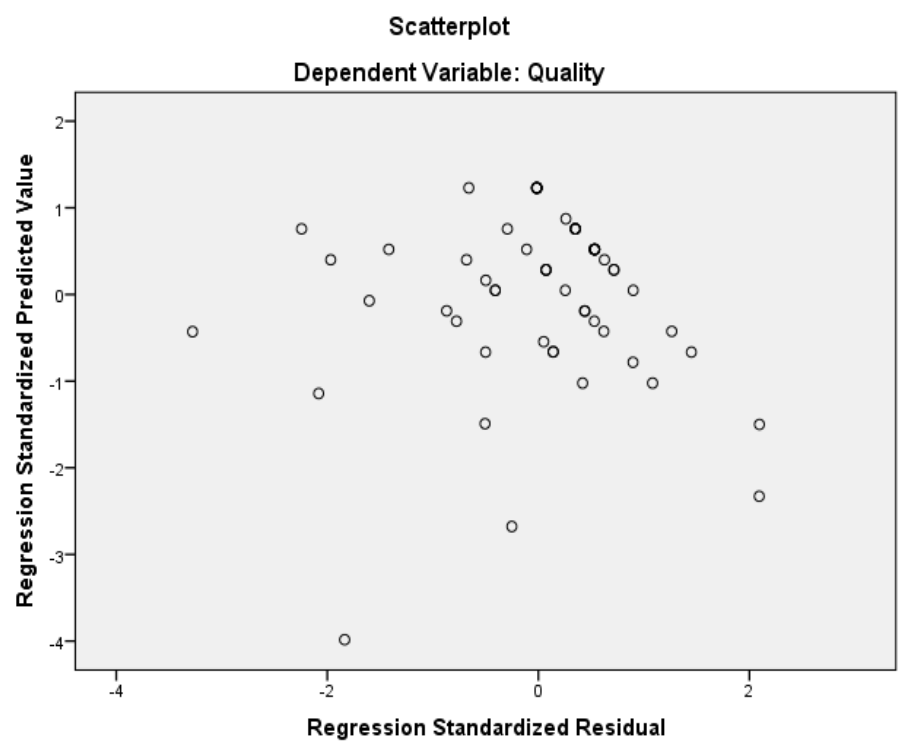

Fig. 3. Heteroscedasticity

Checking the assumption with the graps above, shows that there is no problem regarding heteroscedasticity.

\section{Autocorrelation}

The last assumption to be focused on is autocorrelation assumption. If urbin Watson test is applied the results below are obtained.

$\begin{array}{lllllllll}0 & \mathrm{dl} & \mathrm{du} & 2 & 4-\mathrm{du} & 4-\mathrm{dl} & 4 & \mathrm{~d}\end{array}$

$\mathrm{dl}=1.35$ (from Durbin Watson table)

$\mathrm{du}=1.48$ (from Durbin Watson table)

$4-\mathrm{du}=2.52$

$4-\mathrm{dl}=2.65$

Here, our d value of 1.73 is between du (1.48) and 4-dl (2.65) so we don't reject the Ho which means there is ni autocorrelation problem.

\section{Conclusion/ Discussion}

This study conceptualizes quality as applicable knowledge and accomplishment of goals set in curricula of the subject/ program- effective learning. The conceptualization of the performance on the other hand is participation in active learning, to be able to finalize the tasks that are previously established, getting high test scores, and students' progress in general. Finally, the usage of ICT is understood as teaching and learning by using technology tools and resourcesefficient learning.

The results indicate that participation in the active learning to be able to finalize the tasks that are previously established, getting high test scores, and students' progress have positive effects 
on applicable knowledge and accomplishment of goals set in curricula of the subject programeffective learning. Moreover teaching and learning by using technology tools and resourcesefficient learning again have positive effects on applicable knowledge and accomplishment of goals set in curricula of the subject/ program- effective learning.

The regression equation formulates the linear relationship among the dependent and independent variables. The choices of the participants indicate that one unit increase in active learning, to be able to finalize the tasks that are previously established, getting high test scores, and students' progress in general (1 unit increase refers to 1 level shift of the opinion of the participants with respect to their agreement on the subject matter) will increase the quality (applicable knowledge and accomplishment of goals set in curricula of the subject/ program- effective learning) by 0.283 units. By the same token 1 unit increase in as teaching and learning by using technology tools and resources- efficient learning will increase the quality (applicable knowledge and accomplishment of goals set in curricula of the subject/ program- effective learning) by 0.469 units.

In general the study concludes that both performance and usage of ICT have positive effects on the quality of education provided in higher education institutions in Kosovo.

\section{Future Research Recommendations}

The probable future researchers might focus on different aspects of performance in education and try to understand the relation between performance and motivation in education. Moreover quality is a very comprehensive concept that researchers can analyze quality in education within different frameworks such as real life implementations of what learned from school and lecturers competency about the usage of ICT.

\section{REFERENCES}

1. Ammons, D. N. Municipal Benchmarks: Assessing Local Performance and Establishing Community Standards. Thousand Oaks, Calif.: Sage, 1996.

2. Berg, I. (1972). Education and Performance: Some Problems. The Journal of Higher Education, 43(3), 192-202.

3. Brown Jr, J. (1999). Assessment matters in higher education. McGraw-Hill Education (UK).

4. Callan, P. M., Doyle, W., \& Finney, J. E. (2001). Evaluating State Higher Education Performance Measuring Up 2000. Change: The Magazine of Higher Learning, 33(2), 1019.

5. Clifford, G. J., \& Guthrie, J. W. (1990). Ed school: A brieffor professional education. University of Chicago Press.

6. Ely, R. J. (2004). A field study of group diversity, participation in diversity education programs, and performance. Journal of organizational behavior, 25(6), 755-780.

7. Ferris, J. M. (1992). A contractual approach to higher education performance: with an application to Australia. Higher Education, 24(4), 503-516.

8. Guthrie, J., \& Neumann, R. (2007). Economic and non-financial performance indicators in universities: the establishment of a performance-driven system for Australian higher education. Public Management Review, 9(2), 231-252.

9. Hill, P., Pierce, L. C., \& Guthrie, J. W. (2009). Reinventing public education: How contracting can transform America's schools. University of Chicago Press. 
10. Kaplan, R. S., \& Norton, D. P. (1995). Putting the balanced scorecard to work. Performance measurement, management, and appraisal sourcebook, 66, 17511.

11. Kurien, J. (1981). Towards Universal Elementary Education: Promise and Performance. Economic and Political Weekly, 1608-1618.

12. Metin, H. (2017). Contingency Perspective in Non-governmental Organizations (NGOs). LAP LAMBERT Academic Publishing (April 28, 2017) ISBN-10: 3330079762-ISBN-13: 978-3330079762.

13. Metin, H., \& Coskun, A. (2016). The Effect of Leadership and Organizational Culture on Effectiveness of NGOs: An Empirical Study. Nile Journal of Business and Economics, 316.

14. Richardson, J. T. (1995). Mature students in higher education: II. An investigation of approaches to studying and academic performance. Studies in Higher Education, 20(1), 517.

15. Smith, K. B., \& Meier, K. J. (1995a). Politics and the quality of education: Improving student performance. Political Research Quarterly, 48(2), 329-343.

16. Smith, K. B., \& Meier, K. J. (1995b). Public choice in education: Markets and the demand for quality education. Political Research Quarterly, 48(3), 461-478.

17. Wrinkle, R. D., Stewart Jr, J., \& Polinard, J. L. (1999). Public school quality, private schools, and race. American Journal of Political Science, 1248-1253. 